\title{
Otakar Zich and Prague's 'Semiotic Stage': Reading Performance Avant la Lettre
}

\author{
Veronika Ambros
}

\begin{abstract}
Zich's unique views of dramatic work initiated a performance theory avant la letter. It was, however, as I argue a collective effort of Prague School theorists, whose polemics with Zich and among each other recognized the inherent semiotic potential of Zich's work. Often related to contemporary stage experiments, Zich's ideas explored topics like the mobility and hierarchy of signs, their respective functions, and the position of dramatic text, the concept of the 'actor's figure'. Zich and the discussions he incited are also useful for ideas of transitions between theatre and ceremony that enrich the current approach to the audience, space, and characters on the contemporary stage.
\end{abstract}

\section{Key words}

dramatic work, semiotics of theatre, Chinese theatre, avant-garde theatre, folk theatre, dramatic action, synthetic and analytical theory, dramatic text, actor, puppets, playwright, space, audience

The paper is an outcome of a research project Divadlo jako syntéza uměni: Otakar Zich v kontextu moderní vědy a dnešni potenciál jeho konceptů / Theatre as Synthesis of Arts: Otakar Zich in Context of Modern Science and Actual Potential of His Concepts (GAČR 2016-2018, GA16-20335S). 


\section{Otakar Zich and Prague's 'Semiotic Stage'1}

Otakar Zich's (1879-1934) Aesthetics of Dramatic Art. Theoretical Dramaturgy (ZICH $1931)^{2}$ appears to be one of the best-kept secrets of the semiotics of theatre, drama, and performance, as there are only a few non-Czech experts able to access and assess Zich's work based on their first-hand knowledge of the text. Yet, as Keir Elam, ${ }^{3}$ Michael Quinn, Patrice Pavis, Manfred Pfister, and Herta Schmid testify, Zich's thoughts expressed almost a century ago have shaped theatre semiotics and helped elucidate what he calls the 'dramatic art' in its complexity even today.

Because the author was a man of many scholarly pursuits, his study is as systematic as a work of a mathematician, and at times it appears as the work of a musical composition of a composer, as subjective as the perception of an individual spectator and as precise as a scholarly manual. Admittedly, potential novices to Zich must be cautioned about his book, since it is at first glance, full of variations, digressions, repetitions, and deviations. ${ }^{4}$ Besides, Zich, although systematic in pursuing his arguments, does not provide references to most of his sources, which makes tracing them a truly archaeological effort. Despite such obstacles, reading Zich is both a challenging and rewarding source of inspiration for theatre scholars.

For example, Michael Quinn's The Semiotic Stage: Prague School Theatre Theory is based on Zich's 'pioneering theoretical work' (QUINN 1995: 1). Quinn claims that '[...] the semiotics of theatre and drama has constituted a primary area of inquiry for Prague School writers' (QUINN 1995: 1)5; he regards the Prague Linguistic Circle as 'a school of thought that shared a method and a body of information, not as a legal entity or one that excluded all disagreement' (QUINN 1995: 9).

Although not a semiotician, Zich inspired a semiotic approach to 'dramatic art', that is theatre performance. Besides, as an artist as well as scholar, Zich set an example for a synergy of theory and practice characteristic of several members of the Prague Linguistic Circle. Known also as Prague School, the group did not consist of linguists alone but included a number of artists, literary scholars, and theatre specialists: Roman Jakobson wrote and analysed futuristic poetry in Russia, while in Prague (1920-1939)

1 Quoted from (QUINN 1995).

2 Otakar Zich's Estetika dramatického umèni. Theoretická Dramaturgie (1931) was reprinted as Otakar Zich and Oleg Sus, Estetika dramatického uměni: teoretická dramaturgie in 1977. Ivo Osolsobě and Miroslav Procházka included the article on puppet theatre in their annotated edition of 1986, which will be referenced here if not indicated otherwise. Other highly noted works on Zich include (BURJANEK 1966; ZICH 1965 and 1987 [1975]; DROZD 2010). Brian Locke revived Zich's work as a composer in a scenic production of Zich's opera Vina [Guilt] (1911-1915) in Brno in 2018.

3 Elam refers to Zich in the opening of one of his books: 'Zich's Aesthetics is not explicitly structuralist but exercised a considerable influence on later semioticians, particularly in its emphasis on the necessary interrelationship in the theatre between heterogeneous but interdependent systems' (ELAM: 2002: 5).

4 As Mukařovský notes in his review of the book, many ideas have to be searched for on many pages, and in many parts (MUKAŘOVSKÝ 1982: 288).

5 Quinn refers to the Prague Linguistic Circle, founded in 1926, which though often attacked and its activity several times disrupted, has been in existence ever since. 
he befriended artists of the group Devètsil who assembled the representatives of nine muses as the nine powers of the group's title. Celebrating the experimental Liberated Theatre and the comedians Jiři Voskovec and Jan Werich, Jakobson examined the linguistic basis of the work as the 'noetics and semantics of fun' (JAKOBSON 1987 [1937]: 155-162). The avant-garde theatre and film director Jindřich Honzl, whose knowledge of contemporary stage productions (he was among the first to describe Soviet theatre), as well as theatre history informed his theory and practice, incorporated Zich's ideas into his theoretic views (PROCHÁZKA 1978: 97-116).

The productive collaboration between the ethnographer Petr Bogatyrev and the theatre director E. F. Burian shaped several remarkable stagings of Czech folk poetry in Burian's theatre (AMBROS 2012: 135-146). As Jakobson writes: 'This collaboration also resulted in several instructive essays which Bogatyrev wrote especially for the Programs of Burian's theatre from 1936 through 1939, with one more after the war, in 1946' (JAKOBSON 1985: 297); the list of artists and theorists influenced by Zich could go on.

Thanks to the efforts of Herta Schmid as well as David Drozd and his team, this 'hidden treasure,' will soon be available in translations in German and English respectively, thus expanding the number of those who will be able to recognize the significance of Zich's study. As a result, new readers can learn how much this work informed and inspired the scholars of the Prague School as well as the semiotics of drama and theatre. They can access the discussions about Zich's contribution to Czech aesthetics that served as a basic for the study of drama, theatre, and performance in the Czech Lands, and created the foundation of modern semiotic performance theory avant la lettre.

According to Jan Mukařovský:

$[\ldots]$ in this work, the theatre is viewed in its entire breadth and complexity as a dynamic interplay of all its components, as a unity of forces internally differentiated by reciprocal tensions and as a set of signs and meanings. The theoretical works of Petr Bogatyrev, Jindřich Honzl, E.F.Burian and several younger thinkers are based on the same conception of the theatre. (MUKǍ̌OVSKÝ in DROZD 2016: 61)

Reviewing Zich's original contribution, Jan Mukařovský, his successor as a professor of aesthetics in Prague, emphasizes as one of the basic features of his aesthetics the claim that the understanding of the artwork requires a study of those 'qualities that differentiate art from other phenomena' (MUKAŘOVSKÝ 1982: 284). Zich explored the aesthetic production and reception of the dramatic work and its aesthetic aspects, some of which will be discussed here in my considerations regarding the applicability of Zich's theory today.

Using Mukařovský as a point of departure, I will focus on selected topics within Zich's work that inspired many specialists of and beyond the 'Prague Semiotic Stage': such as his concept of dramatic work that distinguishes synthetic and analytical theory, the technical and pictorial notions (ideas), the dramatic text, the actor, and puppets (expressed in 1923 and included in the edition of 1986) as well as his ideas on the playwright, space, the action, and audience. 


\section{The dramatic art}

When interviewed about his book, Zich expressed his intention to establish a new art, to free the dramatic art from the domination of aesthetics of poetics and music, as well as to consider the dramatic work the entirety of the theatre performance, whereas the dramatic text is only one of its parts (NOVÁK 1932: 465). In short, he wants to present 'systematic treatment of the new art on a par with (souradný) other accepted and known arts' (ZICH 1986: 7).

Zich's shift of focus from text to stage suggests a separate field of study that goes beyond the then newly-formed Theaterwissenschaft. ${ }^{6}$ His basic idea of dramatic art as an 'independent and self-sufficient art' comprises drama, opera ${ }^{7}$, and related 'genres' as a special kind [species] (druh) (ZICH 1986: 13). Unique to dramatic, or in a broader sense theatrical art, is a double perception - both visual and acoustic.

\section{The synthetic theory}

Zich mentions only a few artists (such as G. E. Lessing, D. Diderot, A. Tairov, G. Craig) and scholars (O. Ludwig, G. Fechner). The absence of references to other works might suggest that he developed his ideas without relying too heavily on concrete examples or theories. However, as he acknowledges explicitly, he was indebted to his teacher Hostinský. The section of The Aesthetics of Dramatic Art that Zich devotes to the so-called synthetic theory is based on Hostinský's theory of linking arts (o spojováni uméni) (ZICH 1986: 27).

In Zich's opinion, the synthetic theory presupposes that 'the work of art appears as composite (složené), yet unified, so that the individual components cannot be separated' (ZICH 1986: 29). Describing the process that leads to the creation of the dramatic work, he concludes that it is the 'connection of different artists' (ZICH 1986: 31) rather than arts.

Questioning the priority of text as an acoustic component of performance, Zich's approach highlights the nonverbal aspects of staging and their potential significance, a view that makes his work particularly relevant today. Pantomime and silent film are considered separate genres in which the speech as an expected conventional feature of theatrical acting is absent (ZICH 1986: 51). However, when inserted into the dramatic work these genres might emphasize, as in the case of projected images, a pictorial (optic) dramatic appearance (zjev) (ZICH 1986:185).

Zich sees dramatic art as a new art separated from poetry and music that, however, shares features and contacts in common with both. In contrast to Wagner, whose opin-

6 The study of theatre was separated from the study of German in 1923 at Friedrich-Wilhelms- Universität in Berlin (today Humboldt University).

7 In both cases Zich uses the Czech terms činohra and zpěvohra, expressions which are approximate equivalents of the German Schauspiel and Singspiel, with the German Spiel (hra/play) added to the derivates of čino (associated with action), and zpěvo (singing). These expressions are not directly translatable into English. 
ion Zich calls 'communist' because of his demands for the individual arts to live in a collective all-encompassing work of art (všedile; i.e. 'Gesamtkunstwerk'), he claims that the dramatic work is a 'connection of arts' (ZICH 1986: 29), the components of which are ruled by the same law as the 'laws (conventions) of the respective independent art' (ZICH 1986: 29). However when one of the components (music, poetry, or fine arts) is emphasized (ZICH 1986: 30 f.), such 'theatrical antinomies' might weaken the dramatic quality of the work (ZICH 1986: 30).

Allegedly the text, musical, and scenic components of dramatic work, which are associated with 'poetry, music, and fine arts are expressing aristocratic cravings' - choutky (ZICH 1986: 33), as each of them strives to dominate. The dynamic inherent in such a hierarchy of work of art is close to a notion Mukařovský expressed in 1931, that is the same year Zich's book was published:

Today, the conception of a work of art as a structure - that is, a system of components aesthetically deautomatized and organized into a complex hierarchy that is unified by the prevalence of one component over the others - is accepted in the theory of several arts. (MUKǍ̌OVSKÝ 2016a: 192)

Zich considers 'acting (herectvi) the central, governing component of dramatic art', as it is truly dramatic (ZICH 1986: 33), while Mukařovský's study points to gestures as the dominant element of Chaplin's acting, hence indicating a potential direction Zich's analysis can take. The notions of dominant (which evolved in the Russian Formalism) and hierarchy imply the mobility of signs prominent in the theoretical writing of Mukařovský and other members of the Prague School as well as in the structuralist concept of the semantic gesture as a unifying force of an individual work of art or an oeuvre of an artist.

\section{The analytical theory}

'Dramatic work is the perception we have during the performance' (ZICH 1986: 35). The analytical theory focuses on dramatic art as a new independent and singular art, but not as a connection of several arts (ZICH 1986: 35). The dramatic work perceived visually and acoustically appears to be not only complex but changeable in terms of time. There are two constants of dramatic work: (1) the dramatic personas (osoby dramatu), and (2) the dramatic setting, place or location (misto dramatu) (ZICH 1986: 36), which can be reduced to the mere space, albeit limited architectonically. Although the dramatic persons are variable, their naming as dramatis personae and in the text provides stability to their changing speech, behaviours, and actions, ${ }^{8}$ which together create the plot of the drama, i.e. they 'directly make it' (ZICH 1986: 37).

8 Jiří Veltruský develops this distinction in his Drama jako básnické dílo (VELTRUSKÝ 1999) and the revised English version of Drama as Literature (VELTRUSKÝ 1977). 
In Zich's view, 'The stage [...] is the space (locality) in which the actors perform through their interaction a dramatic action' (ZICH 1986: 178). He calls a space that does not represent anything 'neutral' as 'filled' by the characters (ZICH 1986: 179). ${ }^{9}$ The stage formation has to follow the principle of correspondence between the technical and pictorial (obrazový) image as much as the actor (character - actor's figure) and the director does (interplay... dramatic action) (ZICH 1986: 178). ${ }^{10}$

Quinn in The Semiotic Stage (1995) translates the term obrazový as 'imaginary', which loses the visual aspect stressed by Zich, 'Dramatic art is pictorial art' (uměni obrazové) (ZICH 1986: 56). This is a statement that challenges the alleged realistic affinity of Zich's argument and resonates with contemporary theatre trends. Mukařovský suggests that the expression obrazová predstava [pictorial image] is nothing more than 'a complex and multi-layered meaning'11 (MUKAǨOVSKÝ 1933: 319). To Quinn, Zich’s crucial innovation 'to divide phenomena into two levels, according to the perspective of the observer: "technical and imaginary" [sic!] corresponds roughly to signifier and signified' (QUINN 1995: 49); thus, suggesting a semiotic reading of Zich inherent also elsewhere. ${ }^{12}$

Moreover, the word 'imaginary' is used as a translation of pomyslny regarding space as a product of the spectator's imagination, as discussed by K. Pražáková (PRAŽÁKOVÁ 1921), F. Stiebitz (STIEBITZ 1937), K. Brušák (BRUŠÁK 1991), and E. Stehlíková (STEHLÍKOVÁ 2012). ${ }^{13}$ Honzl mentions the "“acoustic scenery" of the radio drama as examples of signs that signify setting through other than strictly visual [...what he calls] representation' (HONZL 2016: 130). However, as Honzl argues regarding Zich's concept of space, 'Whenever he speaks of the stage, he always has in mind a stage inside a theatre building' (HONZL 2016: 130). Following Zich's notion that 'dramatic art is an art of images and this holds in absolutely every respect' (ZICH 1986: 183) for Honzl: 'The theatre performance is a set of signs' (HONZL 2016: 129).

To Honzl 'the figurative function of the stage is independent of its architectural nature' a claim that contests Zich's insistence on a theatrical building (HONZL 2016: 130). Veltruský (2016b: 250) refers to Zich: 'All the relations between stage figures and characters are projected into space. They constitute what is termed dramatic space, a set of immaterial relations that constantly changes in time as these relations themselves change' (ZICH 1931: 246). ${ }^{14}$

9 Expanding Zich, Honzl speaks about freeing "the concept of "stage" from its being limited to architecture, and we can also free the concept of "actor" from the limitation that regards the actor as a human being who represents a character' (HONZL 2016: 131).

10 Sus traces the term to the German theorist Volkelt: 'significatory image' (významová predstava = Bedeutungsvorstellung), which Sus also translates as 'significatory image' (SUS 1972: 40).

11 'Tato obrazová préedstava nenínic jiného než velmi složitý a mnohonásobně zurstvený význam.' (MUKAǨOVSKÝ 1933: 319)

12 See the comments in the footnotes by the editors.

13 'David Wiles' term "an imagined off-stage world" (WILES 1997: 114) shows that the issues connected with this "imaginary stage" of the classic Czech philologists or the "imaginary action space" of the structuralist Karel Brušák are still alive.' (STEHLÍKOVÁ 2012: 203)

14 Veltruskýs reference does not correspond to the text on the indicated page. 
Zich himself admits that his term dramatic differs from the everyday usage, as it evokes conventionally something emotionally stirring, where 'exciting' can simply replace the word 'dramatic'. It refers to either a written text of a specific literary genre or, in everyday usage, a tense situation or person (ZICH 1986: 40). By contrast, he suggests using the word 'dramatic' only for human action and conduct (ZICH 1986: 40).

The dramatic art appears to be collective, a work of art created or co-created by actors (ZICH 1986: 38). Consequently, Zich excludes the work of a single actor, and therefore potentially also the possibility of monodrama because to him monodrama is not 'drama' unless it is provided with a second person that would substitute a personified power (ZICH 1986: 38).

Later Veltruský observes:

[...] a figure may signify more than one character, for instance, the hunter and the elephant, the groom and the eight highly individualized horses, the obsessed man and the being he is obsessed with. When Jean Cocteau's The Human Voice is performed, the only stage figure signifies not only both the abandoned woman and her former lover but also two different images of the woman - the one conveyed to the audience and the one conveyed to her interlocutor. (VELTRUSKÝ 2016a: 417-418)

According to Zich, all objects that are theatrical signs have a double role: first (and most importantly) they characterize, effectively establishing the characters and the place where the story unfolds; second, they have a functional purpose, of taking part in the dramatic action (ZICH 1986: 184). To Veltruský 'all that is on the stage is a sign' (VELTRUSKÝ 2016c: 148) while Bogatyrev suggests an important modification: 'The theatre only uses those signs of costumes and structures that are necessary for the given drama' (BOGATYREV 2016: 100).

Honzl quotes Zich about dramatic art as 'an art of images' (ZICH 1986: 183) While, Bogatyrev describes the mobility of the stage space in the folk theatre and by extension in ceremonies, Honzl asserts that in contrast to theatre, ritual/ceremony does not have spectators but participants..$^{15}$ This distinction helps reveal the relationship between the stage and the audience in performance and ceremony relevant to the contemporary stage; it shows the complexity of a performance in which both groups can be intertwined or, using Zich's notion of the double role of theatrical signs, one which characterizes the characters and another taking part in the dramatic action ${ }^{16}$ (ZICH 1986: 184).

15 Jindřich Honzl's 'Ritual and Theatre' (DROZD, KAČER and SPARLING 2016: 482-493).

16 See (BOGATYREV 2016: 101). 


\section{The dramatic work}

To Zich a 'dramatic work [is] everything we perceive (see and hear) during a performance in the theatre' (ZICH 1986: 13). He continues, 'The dramatic work can only subjectively come to existence as a mere perception of real production (provozováni) in which both acoustic and visual components have sensory clarity [illustrativeness] (smyslovou názornost) (ZICH 1986: 18). ${ }^{17}$ Consequently, he includes the recipient in his reflection but distinguishes two modes of perception: acoustic and optic, or visual. At the core of his argument (ZICH 1986: 43) are two semantic notions or images (představa): technical (based on the knowledge of theatre), and pictorial or optic (obrazová predstava) that applies to dramatic art and acting.

According to Quinn:

Zich distinguishes between constant and variable elements in the structure of the performance, defining action as the matrix that holds them together. He separates natural action and action on stage through attention to their effects on the spectator, and from this separation derives a further analytical distinction between 'stage action' and 'dramatic action', the first existing in the interplay of the actors and other stage components as a 'technical' phenomenon, while the dramatic action exists as a psychological phenomenon, on the 'imaginary, level of illusion'. (QUINN 1995: 44)

\section{The dramatic text}

By contrast to most conventional examinations of the dramatic text that might comprehend the staging as an adequate or unsatisfactory transposition of the written word into a spoken one, the performance analysis that follows Zich includes various elements like music and fine arts in the process of creating the dramatic work. Thus, Zich achieves the 'dynamic interplay' of various components of performance by insisting that 'the dramatic work is theatre performance' (divadelni predstaveni) (ZICH 1986: 13). As Elam (2002: 5-6) states, 'Zich does not allow special prominence to any one of the components involved: he refuses, particularly, to grant automatic dominance to the written text, which takes its place in the system of systems making up the total dramatic representation.' Quinn affirms: 'The uniqueness of Zich's work in its time was its insistence upon the primacy of performance rather than text' (QUINN 1995: 47).

Zich responded to the accusations that he undervalued the dramatic text by pointing to the significance of its fixed shape that allows it to be presented 'at anytime and anywhere' (ZICH 1986: 349). To him, the dramatic text provides 'a directive how to be shaped on stage', as the 'dramatic values are inherent in the text since the actors actually speak the text and they potentially create their characters and their interplay

17 Inherent in this expression is the emphasis on the visual and acoustic components of the performance (the German equivalent of názornost is Anschaulichkeit). 
according to the text' (ZICH 1986: 349). The dramatic text, however, is not the whole work, but a part. Unlike narrative texts, 'the existential condition of the dramatic work is its performance' (ZICH 1986: 349). This production or staging is 'a real action, i.e. performed by real people (actors) in real space (stage) that takes place in real-time.' When the text is being read, it flows in a 'thought' (myšlený) time and not in a real one (ZICH 1986: 62; emphasis in the original).

Mukařovský refers to Ibsen, who 'inserts a double meaning into the text [...] one meaning is expressed explicitly in words, the other is accessible only through the actor's gestures' (MUKǍ̌OVSKÝ 2016c: 69).

Veltruský (1977: 9) follows Zich's argument when he suggests: 'Theater is not another literary genre but another art.' Yet, his analysis of drama as a poetic work does not agree with Zich's study (see VELTRUSKÝ 1942). Veltruský also modifies Zich and corroborates the linguistic tendency of the Prague School: 'It [i.e. theatre] uses language as one of its materials while for all the literary genres, including drama, language is the only material - though, each organizes it in a different fashion' (VELTRUSKÝ 1977: 9).

Although Zich discusses the division of the text into direct speeches of dramatic persons and stage directions, he includes only the speeches of characters into the dramatic text because the stage directions allegedly do not exist during the performance, and are merely cursory (ZICH 1986: 80). Conversely, Veltruský (1977: 37) suggests 'the meanings are conveyed by two entirely different forms of language - the speeches attributed to the interlocutors and the author's notes (usually called stage directions).' More importantly, according to Veltruský 'the author's annotations fulfil the most elementary condition of the semantic unification of dialogue, which no drama can dispense with. It is not the direct speeches [...] or any of their components that indicate which speech is allotted to whom, so providing information without which the reader could not follow the thread of the dialogue, but the speakers' names which the author puts before the speeches' (VELTRUSKÝ 1977: 41).

Veltruský, who examines drama 'as a genre belonging entirely to the art of literature' (VELTRUSKÝ 1977: 8), discusses Zich's claim regarding drama as 'merely verbal component of theatre' (VELTRUSKÝ 1977: 8). Especially relevant today is his comment that 'drama is not the only literary genre which provides the theatre with the texts it needs' (VELTRUSKÝ 1977: 9).

\section{The playwright}

Zich describes the text not only as a product but also as the creation of the playwright as a segment of the process in which the dramatic work takes place [is in progress] (probihá) (ZICH 1986: 68). He refers to Otto Ludwig, a German playwright and theorist, who said that the playwright immerses himself in his personae (vživa se) (ZICH 1986: 69). To Zich, the dramatic person 'is the playwright's I changed into a new, other I.' This transformation is not reduced only to the playwright but is shared by those 
involved in performing the dramatic art, i.e. actors, the director, and also the composer has this ability albeit each of them relies on the dramatic text (ZICH 1986: 69). Zich attributes this ability also to the audience, who, however, takes the 'figure' as something objective, as the 'actor's figure ${ }^{18}$ on stage. Conversely, it is subjective for the playwright, a part of his consciousness.

Zich defines the transformation of one subject into a different one by using the term předuševněni [roughly, trans-soulment], a term that was criticized by Honzl (HONZL 1940: 111) as being indebted to the psychological foundation of Zich's aesthetics. Yet, it connotes Stanislavsky's perevoploščenie, and Bogatyrev's transfiguration, a term Jakobson used in his obituary for Bogatyrev: 'With such men of the stage as Evreinov, Bogatyrev shares the view that our entire life is saturated with theatrical elements and that now and again we are transfigured [...] Transfiguration appears as a fundamental feature that distinguishes drama from lyric and epic. The dualism of the actor and his role is experienced by the spectator' (JAKOBSON 1985: 294).

The editors of Zich's book trace the term back to an article written in 1915 in which Zich speaks in the context of children's games about a 'reversed metempsychosis' (ZICH 1986: 346). At that time this topic was very popular: for instance, Gustav Meyrinks' Der Golem..$^{19}$ In Zich's view, however, předuševněni, unlike metempsychosis, is a process that leads to a truthful figure.

\section{Acting, actors, and puppets}

To Zich, actors are '[t]hose who can present dramatis personae and perform the dramatic action, which can be repeated and done any time' (ZICH 1986: 41). ${ }^{20}$ The dramatic actions are activities or acts that emerge based on shared acts of human beings, in which we have no practical interest and which have aesthetic effects. Nevertheless, we do not participate, we are merely observers without being immediately in danger (ZICH 1986: 41). Zich includes the fact that not only human beings act, but also supernatural creatures are always personified (ZICH 1986: 38).

Mentioning Aristotle and the fact that tragedy evokes emotionally unpleasant sentiments, which nonetheless cause aesthetic pleasure, Zich recalls the concept of Jean Baptiste Dubos, ${ }^{21}$ a French aesthetician of the $18^{\text {th }}$ century who speaks about the principle of functional pleasure (princip funkčni libosti) (ZICH 1986: 42): 'The advantage

18 Veltruský says, "The literal translation of Zich's own term, herecká postava would be the "actor's figure", an utterly misleading expression. I chose the somewhat barbarous "stage figure"' (VELTRUSKÝ in DROZD 1986: 378).

19 Gustav Meyrink's Der Golem (1913-1914) first appeared in the periodical Die weissen Blätter, and was published as a book in 1915 in Leipzig by Kurt Wolff.

20 'Ti, kteři maji schopnosti prédstavovat dramatické osoby a prédvádět dramatický děj, sluji herci. Takováto dramatická prèdstaveni maji proti dramatickým dějuim prírozeným, životním již tu výhodu, že mohou být konána, kdy je libo, popř́padě i opakována.' (ZICH 1986: 41)

21 Jean-Baptiste Dubos (1670-1742). 
of the art is that it substitutes natural passions with artificial ones [...] which are as if purified' (ZICH 1986: 42).

Zich states that dramatic art is a pictorial art (obrazové umění), which also applies to the art of acting (herectvi). In contrast to a statue, however, an actor uses himself as the material: 'As much as marble is not a sculpture, only shaped marble is, in much the same way, only the shaped actor is the character, with the difference that the actor himself accomplishes the shaping of the character while being shaped himself' (ZICH 1986: 41).

The position of the actor as material and the person as a work create the opposition of presenting and presented, which Ivo Osolsobě and Miroslav Procházka, the editors of the 1986 edition of Zich's book identify as semiotic. They consider the 'theory or semiotics of acting Zich's most important contribution to the theory of acting and theatre in general' (ZICH 1986: 342). Zich differentiates between the figure, i.e. what the actor does and the person, as that what the audience sees and hears. The 'figure is a motoric perception, while the person is the opticallyacoustic perception' (ZICH 1986: 45). The following chart (see Table 1) illustrates the suggested positions (ZICH 1986: 46). Quinn (1995: 79) translated the chart as Zich's phenomenology of acting:

Table 1. Zich's phenomenology of acting

\begin{tabular}{|c|c|c|c|}
\hline Artist & Material & Work & Image \\
\hline Actor & actor himself & stage figure & character \\
\hline Several Actors & actor's selves & action & interplay \\
\hline
\end{tabular}

To Veltruský: 'The stage figure is a set of signs, the stage action, a progression of signs' (VELTRUSKÝ 2016a: 382). Quinn speaks about the Prague School study of theatrical acting as 'highly original theory of acting signification, the explication of the actor's materials and creative processes, and the comparison of theatrical acting with various sub-genres of acting (especially the puppet theatre)' (QUINN 1995: 71). ${ }^{22}$ Quinn connects the stage figure with the perception of the audience: 'The case of the stage figure and its function in the stage work illustrates the Prague School's fundamental premise about the relation of all theatrical components: they exist in an interpenetrating dialectical tension' (QUINN 1995: 82). As Quinn argues '[the] threepart theory of the sign has become the first modern semiotic theory of art' (QUINN 1995: 19).

22 Quinn himself devoted a study to the so-called stage figure in general and to Švejk and celebrity acting in particular. Yana Meerzon (2005) used the concept as her point of departure for her study of Michael Chekhov. 


\section{Puppets}

The topic of acting, however, was already central in Zich's seminal study on a seemingly secondary topic - puppet theatre. The third edition of Zich's book acknowledges the significance of Zich's seminal 1923 study. Some important conclusions about puppets, however, are in the book itself. As Honzl says: 'Zich in the Aesthetics explains the Zich of his study about puppets' (HONZL 1940: 110). For example, the puppet theatre is mentioned as an exception if it comes to theatre performed by one individual, unlike an actor "who is an artist presenting a thought person [perhaps, even "fictional". - V. A.] through himself' (ZICH 1986: 48). ${ }^{23}$ A puppeteer 'does not present a dramatic person that is made by each of his puppets to whom he lends his voice and play' (ZICH 1986: 48). ${ }^{24}$ Each of the figures is technically bifurcated into a stable component, which is the puppet made out of some matter (close to sculpture) and a variable one performed (mostly all of them by the principal).

Zich distinguishes two functions of puppets:

(a) We may consider the puppets as puppets, i.e., we will emphasize their lifeless material. This material then is something real for us and we cannot take seriously their speech and movements, their 'expressions of life'; they strike us as comic, grotesque. The fact that the puppets are small, that they are at least partially (in the face, in the body) rigid, and that their movements are accordingly awkward, 'wooden,' contributes even more to their comical appearance. This is not crude grotesquery, but a subtle humorousness using which these little figures, apparently behaving like little people, affect us. We consider them puppets, but they want us to consider them people, and they certainly make us merry! Everyone knows that puppets do have such an effect.

(b) There is, however, another possibility. Puppets can be understood as living beings, if we emphasize their manifestations of life (movements and speech), and conceive of these expressions as real. The consciousness of the actual lifelessness of the puppets then recedes and surfaces only as a sense of something inexplicable, as a mystery evoking our wonder. In this case, the puppets affect us mysteriously. If they had a real human size and if their facial expressions were as perfect as possible, this manner of conceiving them would produce terror in us. (ZICH 2015: 506-507)

As Quinn declares:

In some cases, the puppet theatre may even illuminate theatrical phenomena that are hard to explain independently, such as the stage assistant in Kabuki acting. The Prague School

23 'Herec je umělec predstavujici myšlenou osobu sebou samým.' (ZICH 1986: 48)

24 '...loutkář nepředstavuje dramatickou osobu; to činí každá z jeho loutek, jimž propůjčuje mluvu i hru. Technicky je tu tedy každá "postava” rozdvojena ve složku stálou, již je loutka (z nějaké hmoty, čimž se bliži soše) a proměnlivou, již provádi (zpravidla pro všechny) "principal”.' (ZICH 1986: 48) 
writers were among the first aesthetic theorists to follow the lead of Kleist and Craig in taking puppetry seriously, as a challenge to aesthetic analysis, and their attention to its problems resulted not only in a greater understanding of puppetry but of all kinds of acting and theatre. (QUINN 1995: 92)

Zich's short article was published in 1923, at the same time as Bogatyrev's and Mukařovský's related texts (AMBROS 2011). Subsequently, all three authors returned to the topic, albeit in a different way. Mukařovský, just as Jakobson, was drawn to statues, while Bogatyrev and Veltruský discussed Zich in their studies on puppets.

In the chapter on stylization Zich returns to puppets and also to his ideas from 1923. The puppet shows a large difference between the figure and a person: either the puppet as a lifeless, mechanical 'figure' presenting a living person appears as ridiculous (ZICH 1986: 288) or by emphasizing its life quality the fact that the figure is lifeless, mechanical has a mysterious, ghastly effect (přišerný) (cf. Commendatore). Zich also stresses that the puppet theatre is well suited for artistic (výtvarnou) stylization (ZICH 1986: 289); he mentions the connection between fine art and actor that allegedly 'alerted Gordon Craig to puppets' (ZICH 1986: 187).

\section{Audience}

Remarkably, throughout the book, Zich pays special attention to the role of the audience. On the one hand, he does this even before the rise of reader response theory or the concretization of the literary work of art in the terminology of Felix Vodička inspired by Polish phenomenologist Roman Ingarden. Karl Bühler's model of human communication was also published only in 1934. On the other hand, Zich's emphasis comes before artistic experiments like Burian's performance in the corridor that broke the architectural conventions of the dramatic space and the convention of dividing audience and actors into separate spaces, thus also introducing a new approach to performance analysis. ${ }^{25}$ Veltruskýs study of this staging exemplifies what Honzl observed, 'Zich prepared material for a philosophical and aesthetical solution of the problem of sign [semiotic] quality (znakovost)' (VELTRUSKÝ 1979). In an article published posthumously in 2016, Veltruský (VELTRUSKÝ 2016d: 232) returns to Zich, Bogatyrev and Honzl's criticism of Bogatyrev's notion of the sign quality of an actor by pointing out that an actor is not only a sign but also a human being with all his qualities [...]' Veltruský considers this one of the most important characteristics that distinguish the sign quality of theatre from other arts' (HONZL 1940: 107-112).

The breadth of Zich's activities contributed to the flexibility and range of his analytical apparatus applicable to the contemporary stage and away from the alleged realistic tradition mentioned in comments by Ivo Osolsobě and Miroslav Procházka, the editors

25 'A puppet which represents a character has only those features of a real person which are needed for the given dramatic situation; all the components of a puppet are intentional signs.' (VELTRUSKÝ 1979: 69) 
of the 1986 edition. Unlike Zich, who refers to realism as an artistic trend (ZICH 1986: 278), Osolsobě does not describe the term like those 'theoreticians and historians of art - in particular, of literature - [...] as if the term were a bottomless sack into which everything and anything could be conveniently hidden away' (JAKOBSON 1987: 27).

Yet, Zich's approach avoids easy solutions, questions traditional terminology and provides many stimuli for the analysis of folk theatre (Bogatyrev), medieval stage (Veltruský), Chinese Theatre and imaginary space (Brušák), acting and puppets (Veltruský, Bogatyrev). To sum up, Zich has been an inspiration for performance studies avant la lettre, in many respects up-to-date, and certainly worth a thorough analysis in the contemporary context.

\section{Bibliography}

AMBROS, Veronika. 2011. Puppets, Statues, Men, Objects, and the Prague School. Theatralia 2 (2011): 74-88.

AMBROS, Veronika. 2012. Petr Bogatyrev (1893-1971) et E. F. Burian (1904-1959): Entre Formalisme et Structuralisme, entre Ethnographie et Sémiotique du Théâtre. In Sergei Tschougounnikov and Celine Trautmann-Walter (eds.). Petr Bogatyrev et les Débuts du Cercle de Prague. Recherches Ethnographiques et Theatrales. Paris: Sorbonne Nouvelle, 2012: 135-146.

BOGATYREV, Petr. 1982. A Contribution to the Study of Theatrical Signs. In Peter Steiner (ed.) and John Burbank (transl.). The Prague School: Selected Writings, 1929-1946. Austin: Texas UP, 1982: 55-64.

BOGATYREV, Petr. 2016. Theatrical Signs. In David Drozd, Tomáš Kačer and Don Sparling (eds.). Theatre Theory Reader: Prague School Writings. Prague: Karolinum Press, 2016: 99-114.

BRUŠÁK, Karel. 1991. Imaginary Action Space in Drama. In Herta Schmid and Hedwig Král (eds.). Drama und Theater: Theorie - Methode - Geschichte. München: Otto Sagner, 1991: 144-162.

BURJANEK, Josef. 1966. Otakar Zich. Brno: St. pedag. nakl., 1966.

DROZD, David, Tomáš KAČER and Don SPARLING (eds.). Theatre Theory Reader: Prague School Writings. Prague: Karolinum Press, 2016.

DROZD, David. 2010. Chybějící část recepce Zichova opus magnum [The Missing Part of the Reception of Zich's Opus Magnum]. Theatralia 13 (2010): 2: 214-218.

ELAM, Keir. 2002. The Semiotics of Theatre and Drama. $2^{\text {nd }}$ ed. London/New York: Routledge, 2002.

HONZL, Jindřich. 1940. Objevené divadlo v lidovém divadle českém a slovenském [Discovered Theatre in Czech and Slovak Folk Theatre]. Slovo a slovesnost 6 (1940): 2: 107-111.

HONZL, Jindřich. 2016. The Mobility of the Theatrical Sign. In David Drozd, Tomáš Kačer and Don Sparling (eds.). Theatre Theory Reader: Prague School Writings. Prague: Karolinum Press, 2016: 129-146.

JAKOBSON, Roman. 1985. Peter Bogatyrev, (29.1.93-18.VIII.71). Expert in Transfiguration. Selected Writings, VII, Berlin, NY, Amsterdam: Mouton, 1985: 293-304.

JAKOBSON, Roman. 1987a. An Open Letter from Roman Jakobson to Jiří Voskovec and Jan Werich on the Epistemology and Semantics of Fun. Transl. by M. Quinn. Stanford Slavic Studies (1987): 1: 155-162. 
JAKOBSON, Roman. 1987b. On Realism in Art. In Krystyna Pomorska and Stephen Rudy (eds.). Language in Literature. Cambridge, Mass./London: Harvard UP, 1987: 19-28.

MEERZON, Yana. 2005. The Path of a Character: Michael Chekhov's Inspired Acting and Theatre Semiotics. Frankfurt am Main: Peter Lang, 2005.

MUKǍ̌OVSKÝ, Jan. 1933. Otakar Zich: Estetika dramatického umění (recenze) [Otakar Zich: The Aesthetics of Dramatic Art (review)]. Časopis pro moderni filologii a literaturu XIX (1933): 318-326.

MUKAǨOVSKÝ, Jan. 1940. Dialog a Monolog [Dialogue and Monologue]. Listy Filologické / Folia Philologica 67 (1940): 3/4: 139-160.

MUKAŘOVSKÝ, Jan. 1978. Time in Film. In John Burbank and Peter Steiner (transl. and eds.). Structure, Sign, and Function. Selected Essays. New Haven/London: Yale University Press, 1978: 191-200.

MUKAŘOVSKÝ, Jan. 1982. Otakar Zich. In Jan Mukařovský. Studie z poetiky. Prague: Odeon, 1982: 284-289.

MUKAǨOVSKÝ, Jan. 2016a. An Attempt at a Structural Analysis of an Actor's Figure (Chaplin in City Lights). In David Drozd, Tomáš Kačer and Don Sparling (eds.). Theatre Theory Reader: Prague School Writings. Prague: Karolinum Press, 2016: 192-199.

MUKǍ̌OVSKÝ, Jan. 2016b. Dialogue and Monologue. In David Drozd, Tomáš Kačer and Don Sparling (eds.). Theatre Theory Reader: Prague School Writings. Prague: Karolinum Press, 2016: 220-246.

MUKAǨOVSKÝ, Jan. 2016c. On the Current State of the Theory of Theatre. In David Drozd, Tomáš Kačer and Don Sparling (eds.). Theatre Theory Reader: Prague School Writings. Prague: Karolinum Press, 2016: 59-75.

NOVÁK, Bohumil. 1933. Rozhovor s Otakarem Zichem [An Interview with Otakar Zich]. Čin 4 (1933): 465-469.

PRAŽÁKOVÁ, Klára. 1921. Pomyslné jeviště [Imaginary Stage]. Jeviště II (1921): 390-392.

PROCHÁZKA, Miroslav. 1978. Jindřich Honzl a otázky teorie divadelního znaku. (Šestidílná studie o zkoumání sémiotických otázek v teatrologických úvahách Jindřicha Honzla) [Jindřich Honzl and Isues of the Theory of the Theatrical Sign (A Study in Six Parts of Studying Semiotic Issues in Jindřich Honzl's Inquiries in Theatre Studies]. Estetika 15 (1978): 2: 97-116.

QUINN, Michael L. 1988. Švejk's Stage Figure: Illustration, Design, and the Representation of Character. Modern Drama 31 (1988): 3: 330-339.

QUINN, Michael L. 1990. Celebrity and the Semiotics of Acting. New Theatre Quarterly 6 (1990): 22: 154-161.

QUINN, Michael L. 1995. The Semiotic Stage: Prague School Theatre Theory. New York: Peter Lang, 1995.

STIEBITZ, Ferdinand. 1937. Pomyslné jeviště v antickém a v moderním dramatě [The Imaginary Stage in Classical and Modern Drama]. Věda a život (1937): 3: 229-242.

SUS, Oleg, Ladislav SOLDÁN and Dušan JEŘÁBEK. Geneze sémantiky hudby a básnictví v moderni české estetice: dvě studie o Otakaru Zichovi [Development of Musical and Poetic Semantitcs in Modern Czech Aesthetics: Two Studies about Otakar Zich]. Brno: Filozofická fakulta Masarykovy univerzity, 1992.

SUS, Oleg. 1972. On the Genetic Preconditions of Czech Structuralist Semiology and Semantics. Poetics 1 (1972): 4: 28-54.

SZONDI, Peter. 1967. Theorie des modernen Dramas. Frankfurt am Maine: Suhrkamp, 1967.

VELTRUSKÝ, Jiří. 1942. Drama jako básnické dílo [Drama as Literature]. In Bohuslav Havránek and Jan Mukařovský (eds.). Čteni o jazyce a poesii [Reading about Language and Poetry]. Prague: Družstevní práce, 1942: 403-502. 
VELTRUSKÝ, Jiří. 1977. Drama as Literature. Lisse: Peter de Ridder Press, 1977.

VELTRUSKÝ, Jiří. 1979. Theatre in the Corridor. E. F. Burian's Production of 'Alladine and Palomides'. The Drama Review 23 (1979): 4: 67-80.

VELTRUSKÝ, Jiří. 1999. Drama jako básnické dílo [Drama as Literature]. Brno: Host, 1999.

VELTRUSKÝ, Jiří. 2016a. A Contribution to the Semiotics of Acting. In David Drozd, Tomáš Kačer and Don Sparling (eds.). Theatre Theory Reader: Prague School Writings. Prague: Karolinum Press, 2016: 376-424.

VELTRUSKÝ, Jiří. 2016b. Dramatic Text as a Component of Theatre. In David Drozd, Tomáš Kačer and Don Sparling (eds.). Theatre Theory Reader: Prague School Writings. Prague: Karolinum Press, 2016: 247-268.

VELTRUSKÝ, Jiří. 2016c. People and Things in the Theatre. In David Drozd, Tomáš Kačer and Don Sparling (eds.). Theatre Theory Reader: Prague School Writings. Prague: Karolinum Press, 2016: $147-156$.

VELTRUSKÝ, Jiří. 2016d. Strukturalismus a divadelní věda [Structuralism and Theatre Studies]. Theatralia 19 (2016): 1: 231-237.

ZICH, Jaroslav. 1965. Sdělovací schopnost hudby [Communicative Abilities of Music]. Hudebni věda II (1965): 31-75.

ZICH, Jaroslav. 1987 [1975]. Kapitoly a studie z hudebni estetiky [Chapters and Studies in the Aesthetics of Music]. Prague: Supraphon, 1987.

ZICH, Otakar and Oleg SUS. 1977. Estetika dramatického umění: teoretická dramaturgie [The Aesthetics of Dramatic Art: A Theoretical Dramaturgy]. Würzburg: Jal-reprint, 1977.

ZICH, Otakar. 1931. Estetika dramatického uměni [The Aesthetics of Dramatic Art]. $1^{\text {st }}$ ed. Prague: Melantrich, 1931.

ZICH, Otakar. 1986. Estetika dramatického uměni: teoretická dramaturgie [The Aesthetics of Dramatic Art: A Theoretical Dramaturgy]. $2^{\text {nd }}$ ed. Prague: Panorama, 1986.

ZICH, Otakar. 2015. Puppet Theatre. Transl. by Pavel Drábek. Theatralia 18 (2015): 2: 505-513. 


\section{Professor Veronika Ambros}

Centre for Comparative Literature, Department of Slavic Languages and Literatures University of Toronto, Isabel Bader Theatre, 93 Charles Street West,

Toronto, Ontario, M5S 1K9, Canada

veronika.ambros@utoronto.ca

Veronika Ambros was born in Prague. She received her Bachelor's Degree in Slavic Studies in Köln, and Master's Degree and Doctor of Philosophy in Slavic Studies and Political Science at the Free University in Berlin. She worked at the Free University in Berlin and University of Toronto. She is Professor emerita since 2018. She published a book Pavel Kohout und die Metamorphosen des sozialistischen Realismus [Pavel Kohout and the Metamorphoses of Socialist Realism] (Peter Lang, 1993) and co-edited Structuralism(s) Today: Paris, Prague, Tartu with Roland Le Huenen, Adil D'Sousa and Andrés Pérez-Simón (Legas, 2009). Her interest in the history of theatre resulted in a number of further publications, which include 'Fictional World and Dramatic Text: Václav Havel's Descent and Ascent' (Style 25(2), 1991), 'The Great War as a Monstrous Carnival: Jaroslav Hašek's Švejk' (in History of the Literary Cultures of East-Central Europe, vol.I, edited by Marcel Cornis-Pope and John Neubauer, John Benjamins, 2004); 'Fuzzy Borderlines - The Čapeks' Robots, Insects, Women and Men' (in History of the Literary Cultures of East-Central Europe, vol. III, edited by Marcel Cornis-Pope and John Neubauer, John Benjamins, 2007); 'Daleká cesta. Svědecká výpověd' Alfréda Radoka' (in Alfréd Radok mezi filmem a divadlem, edited by Eva Stehlíková, AMU, 2007); 'Czech Drama' (in Western Drama through the Ages, edited by Kimball King, Greenwood Press, 2007); 'America Relocated - Karel Čapek's Robots between Prague, Berlin and New York' (in Performance, Exile and 'America', edited by Yana Meerzon and Silvija Jestrovic, Palgrave, 2009); and 'How did the Golems (and Robots) Enter Stage and Screen and Leave Prague?' (in History of the Literary Cultures of East-Central Europe, vol. IV, edited by Marcel Cornis-Pope and John Neubauer, John Benjamins, 2010). 